\title{
HABITUS PEMBALAK LIAR PADA MASYARAKAT KETAMBE KABUPATEN ACEH TENGGARA
}

\author{
Muhammad Al Bahri, Nirzalin ${ }^{1)}$ \\ ${ }^{1}$ Program Magister Sosiologi FISIP Universitas Malikussaleh, nirzalin@ unimal.ac.id
}

\section{ABSTRACT}

This research examines the "Illegal Logging Habitus in Ketambe Community, Aceh Tenggara District". The purpose of this research is to know and understand how illegal logging practices, the process of socializing illegal logging habits and why illegal logging practices are still carried out even though the community already knows the risks will have implications for natural disasters. This research was conducted in Ketambe District, Aceh Tenggara District, Aceh Province. This study uses the Habitus theory developed by Pierre Bourdieu. This study used a qualitative descriptive approach, the data in this study were collected through observation, interviews, and documentation. The results of this study explain that the practice of illegal logging in Ketambe Subdistrict, Aceh Tenggara District is carried out systematically by timber shopkeepers who have the capital and strategic positions as figures in society and their relationships with unscrupulous state apparatus and provide gratification to these State officials in order to maintain their business. in the logging sector. The socialization of habitus to illegal logging in the ketambe community through transformation results from empirical experiences by being heard, shown, and taught to act so that in order to survive, they are taught with explanations of how to act as loggers. As well as the motive that encourages people to continue to carry out illegal logging actions is a pragmatic perspective about obtaining economic benefits in a short time coupled with very limited decent work opportunities so that it encourages the action to continue continuously so that they can survive in the era of modernization and globalization which is all complex.

Keyword: Illegal Logging, Socialization Practices, Habitus, Ketambe People

\section{ABSTRAK}

Penelitian ini mengkaji tentang "Habitus Pembalakan Liar pada Masyarakat Ketambe Kabupaten Aceh Tenggara". Tujuan studi ini adalah mengetahui dan memahami praktik pembalakan liar, proses sosialisasi habitus pembalakan liar, dan alasan praktik ini tetap dilakukan meskipun diketahui resikonya akan berimplikasi pada bencana alam. Penelitian dilakukan di Kecamatan Ketambe Kabupaten Aceh Tenggara. Studi ini menggunakan teori habitus yang dikembangkan oleh Pierre Bourdieu. Pendekatan penelitian yaitu deskriptif kualitatif, dimana data dikumpulkan melalui observasi, wawancara, dan dokumentasi. Hasil penelitian menemukan bahwa praktik pembalakan liar di Kecamatan Ketambe Kabupaten Aceh Tenggara dilakukan secara sistematis oleh para toke kayu yang memiliki modal. Mereka memiliki posisi sosial yang strategis sebagai tokoh masyarakat dan memiliki relasi dengan oknum aparatur negara. Gratifikasi diberikan kepada oknum aparatur negara agar dapat mempertahankan kelangsungan usahanya. Sosialisasi habitus pembalak liar pada masyarakat Ketambe melalui transformasi hasil dari pengalaman empiris dengan cara diperdengarkan, diperlihatkan, dan diajarkan untuk bertindak sehingga agar bisa bertahan hidup maka mereka diajarkan dengan penjelasanpenjelasan tentang bagaimana cara untuk bertindak sebagai pembalak. Motif yang mendorong masyarakat untuk tetap melakukan tindakan pembalakan liar bersifat pragmatis yaitu memperoleh keuntungan ekonomi dalam waktu singkat ditambah dengan keterbatasan lapangan pekerjaan sehingga hal tersebut mendorong tindakan tersebut tetap berlangsung secara terus-menerus.

Kata Kunci: Pembalak Liar, Praktik Sosialisasi, Habitus, Masyarakat Ketambe 


\section{PENDAHULUAN}

Sejak masa penjajahan kolonial Belanda pada tahun 1823, masyarakat Ketambe di Kabupaten Aceh Tenggara sudah turun-temurun memanfaatkan hutan dan bercocok tanam padi, jagung, kopi, karet dan komoditi lainnya sebagai sumber dalam memenuhi kebutuhan hidup mereka. Bilamana memanfaatkan hutan masyarakat mengambil seperlunya atau secukupnya dengan menggunakan peralatan yang masih sederhana seperti kapak, parang, gergaji tangan, dan alat manual lainnya.

Sejak awal tahun 1980-an, masyarakat di kawasan Ketambe telah dipengaruhi oleh modernisasi yang ditandai dengan penggunaan peralatan yang lebih modern dan efisien untuk mengekploitasi hutan seperti gergaji mesin dan truk-truk pengangkut muatan kayu dan ditambah dengan masuk dan beroperasinya kilang-kilang pengolahan kayu. Hal ini membuat masyarakat cenderung lebih mudah dan cepat untuk mengeksploitasi hutan dengan skala yang jauh lebih besar. Masyarakat Ketambe pada umumnya menebang kayu gelondongan untuk dijual kepada beberapa pengusaha kilang kayu, sehingga kayu tersebut diolah dan dijual kembali ke luar daerah Aceh Tenggara.

Sejak awal tahun 2000-an sampai saat ini Pemerintah Pusat melalui Kementerian Kehutanan telah melarang kegiatan pembalakan liar (illegal logging) serta melarang keberadaan kilang-kilang kayu tersebut. Alasannya ialah beroperasinya kegiatan tersebut membuat hutan yang dulunya lebat menjadi gundul dan berdampak pada bencana alam yang kerap terjadi, seperti banjir bandang yang merusak pemukiman, lahan pertanian, dan aktivitas masyarakat setempat.

Sebenarnya masyarakat telah mengetahui bahwa penyebab munculnya bencana alam di daerah Ketambe karena aktivitas eksploitasi hutan seperti illegal logging yang mereka lakukan. Namun kegiatan ini masih marak terjadi. Dewasa ini, kayu langsung diolah di dalam hutan atau pembalak tidak lagi menjual kayu gelondongan ke kilang-kilang pengolahan kayu. Efek yang ditimbulkan dari kegiatan tersebut masih tetap sama, yang berbeda hanya cara beroperasinya.

Praktik pembalakan liar menjadi suatu hal yang mengalami pelanggengan atau menjadi kebiasaan masyarakat. Praktik ini disosialisasikan terhadap keluarga secara turun-temurun sebagai profesi atau ladang mencari nafkah. Kebiasaan tersebut tetap dilakukan walaupun mereka mengetahui resiko dan implikasinya pada terjadinya bencana alam di wilayah Ketambe. Kebiasaan masyarakat Ketambe melakukan praktik pembalakan liar tumbuh dari sosialisasi orang tua atau keluarga yang terinternalisasi dalam diri individu yang mengarah pada pola abadi dan ditransfer dari satu individu ke individu lainnya.

2 | Jurnal Ilmu Sosial dan Ilmu Politik Malikussaleh (JSPM) Volume 1 Nomor 1 Periode Januari-Juni 2020 
Berdasarkan fenomena diatas menarik dikaji mengapa praktik pembalakan liar tetap lestari, meskipun masyarakat mengetahui pembalakan liar itu merupakan pemicu dari terjadinya bencana alam. Berdasarkan latar belakang di atas, maka dapat dirumuskan beberapa masalah penelitian. Pertama, tentang praktik pembalakan liar di Kecamatan Ketambe Kabupaten Aceh Tenggara. Kedua, proses sosialisasi habitus pembalak liar di dalam keluarga masyarakat Ketambe sehingga habitus pembalakan liar tetap bertahan dan diturunkan dari generasi ke generasi berikutnya. Ketiga, motif yang melatarbelakangi praktik pembalakan liar tetap dilakukan meskipun masyarakat sudah mengetahui resikonya akan berimplikasi pada bencana alam.

Kajian mengenai perilaku masyarakat dalam hal illegal logging bukanlah hal baru. Beberapa peneliti sebelumnya telah membahas tema yang sama diantaranya studi Hasan (2009) dan Narindrani (2018). Namun kedua peneliti tersebut tidak memfokuskan kajian mereka pada sisi pembentukan habitus, melainkan pada sisi upaya penanggulangan dan kajian fiqh illegal logging. Demikian halnya dengan studi tentang pembentukan habitus, pernah dilakukan namun dalam konteks dan studi kasus yang berbeda dengan penelitian ini oleh Fithri \& Handoyo (2015) serta Aksan (2016).

\section{Teori Habitus}

Habitus bisa dikatakan sebagai kebiasaan yang ada di dalam masyarakat yang sifatnya terstruktur serta menentukan dan membimbing cara berpikir dan bertindak seseorang. Eksistensi habitus mengarahkan seseorang untuk berpikir dan berperilaku sesuai dengan yang diharapkan oleh struktur objektif (Ritzer \& Goodman, 2010). Habitus diperoleh melalui proses belajar dalam jangka panjang yang terinternalisasi dan terakulturasi dalam diri seseorang (Haryatmoko, 2016). Namun habitus bersifat tidak tetap atau permanen dalam diri seseorang. Habitus dapat berubah melalui pengkondisian tertentu (Takwin, 2006). Dengan demikian, habitus dapat dilihat sebagai hasil dialektika antara struktur objektif dan representasi subjektif (Swartz, 1997). Adapun fenomena yang diangkat dalam studi ini melihat bagaimana sistem-sistem disposisi pembalakan liar tahan waktu dan dapat diwariskan, struktur-struktur terbentuk, kemudian membentuk suatu habitus pembalakan liar pada masyarakat Ketambe. Mengacu pada gagasan Koentjaraningrat (2000) masyarakat Ketambe itu sendiri bisa dilihat sebagai suatu kesatuan manusia yang saling berinteraksi dan saling terikat oleh suatu rasa dan identitas yang sama dalam dirinya. Masyarakat Ketambe merupakan masyarakat yang majemuk, namun suku yang dominan menempati kawasan tersebut adalah suku Alas dan Gayo.

3 | Jurnal Ilmu Sosial dan Ilmu Politik Malikussaleh (JSPM) Volume 1 Nomor 1 Periode Januari-Juni 2020 


\section{METODE PENELITIAN}

Lokasi penelitian ini dilakukan di Kecamatan Ketambe, Kabupaten Aceh Tenggara, Provinsi Aceh. Adapun alasan peneliti memilih lokasi penelitian tersebut, dikarenakan kebiasaan masyarakat melakukan kegiatan illegal logging secara turun-temurun yang berdampak pada kerusakan hutan dan menimbulkan bencana alam setiap tahun. Pendekatan penelitian dilakukan dengan metode kualitatif yang bersifat deskriptif. Informan penelitian ini meliputi 3 kategori informan (Hendarsono dalam Suyanto dan Sutinah, 2005: 171-172) diantaranya informan kunci yaitu pelaku illegal logging dan penadah kayu, informan utama yaitu tukang tarik kayu, dan informan tambahan yaitu masyarakat Ketambe. Sumber data dalam penelitian ini adalah data primer dan data sekunder. Teknik pengumpulan data dilakukan dengan cara observasi, wawancara, dan studi dokumentasi. Teknik analisis data dilakukan dengan empat langkah, yakni koleksi data, reduksi data, penyajian data, dan terakhir penarikan kesimpulan (Sugiyono, 2011).

\section{HASIL DAN PEMBAHASAN}

\section{Praktik Pembalakan Liar di Kecamatan Ketambe Kabupaten Aceh Tenggara}

Sumber daya hutan di kawasan Ketambe sangat melimpah, terutama yang berada di hutan lindung. Untuk melindungi kelestarian hutan Indonesia dari tindakan pembalakan liar yang telah merugikan lingkungan, pemerintah mengeluarkan Peraturan Menteri Kehutanan Republik Indonesia Nomor P.38/MenhutII/2009 tentang Standard dan Pedoman Penilaian Kinerja Pengelolaan Hutan Produksi Lestari dan Verifikasi Legalitas Kayu pada Pemegang Izin atau pada Hutan Hak.

Peraturan yang dikeluarkan berupa sistem verifikasi legalitas kayu (SPLK). Sistem ini merupakan sistem pelacakan yang disusun secara multi stockeholder guna memastikan sumber kayu yang beredar dan diperdagangkan di Indonesia menganut beberapa prinsip utama, yaitu memberantas produksi kayu hasil tindakan pembalakan liar, perwujudan good forest government, serta menuju permintaan atas jaminan legalitas kayu dalam bentuk sertifikasi dari pasar internasional. Upaya ini dilakukan guna mengatasi pembalakan liar dan deforestasi pada hutan. Namun realitasnya di lapangan kasus yang seharusnya diproses secara hukum dan diadili, tidak dilakukan secara totalitas. Maka pemerintah perlu pendekatan pendamping, yaitu melalui sertifikasi dan sosialisasi tentang perlunya izin verifikasi dan legalitas kayu sehingga kayu diketahui sumbernya.

Masyarakat di Kecamatan Ketambe Kabupaten Aceh Tenggara yang merambah kawasan hutan lindung sebagian besar belum mengetahui prosedur untuk membuat dan mendapatkan izin 
sistem verifikasi legalitas kayu. Hal ini dilatarbelakangi oleh pendidikan yang rendah dan masyarakat masih beranggapan bahwa membuat izin itu sulit karena mereka tentunya kekurangan syarat-syarat untuk kelengkapan data yang diperlukan dalam mendapatkan izin merambah hutan. Keadaan ini dimanfaatkan oleh pemilik modal untuk mempekerjakan masyarakat setempat menjadi eksekutor di lapangan. Selain itu, oknum aparatur negara ikut mengintimidasi serta melakukan tindakan pungli dengan dalih tindakan pembalakan liar adalah suatu tindakan yang melanggar hukum.

Kondisi inilah yang mendorong masyarakat bekerja secara terselubung di lapangan sebagai eksekutor kayu. Mereka mengikuti prosedur tidak resmi dalam melakukan tindakan pembalakan liar, yaitu bekerjasama dengan berbagai pihak seperti pemilik modal yang mempunyai relasi yang kuat dengan oknum aparatur negara. Dengan begitu mereka beranggapan dapat terhindar dari jeratan hukum. Dengan adanya relasi dan kerjasama tersebut, praktik pembalakan liar terjadi secara berkesinambungan sehingga membuat eskalasi deforestasi serta resiko terjadinya krisis lingkungan dan bencana alam meningkat.

Maraknya tindakan terkait perusakan hutan membuat pemerintah mengeluarkan kebijakan pemanfaatan tanah dalam kawasan hutan. Pengaturan pemanfaatan hutan sangat penting dalam rangka perlindungan hukum terutama pada rakyat yang memanfaatkan bidang tanah yang ada di kawasan hutan. Pemerintah berharap masyarakat mendapatkan manfaat dari pengelolaan tanah di dalam hutan melalui konsensi lahan bagi masyarakat di kawasan Ketambe. Konsep pemberdayaaan masyarakat yang dibangun oleh pemerintah dilakukan dengan mengubah dan mengembangkan kemampuan masyarakat dari profesi sebagai pembalak liar menjadi petani komoditi unggulan seperti karet, kopi, jagung, dan komoditi lainnya sehingga masyarakat mampu bertahan dan mengembangkan diri secara mandiri.

Namun pada kenyataannya laju deforestasi di Kecamatan Ketambe semakin meningkat setiap tahunnya karena masyarakat menilai bahwa kebijakan pemerintah dalam hal pemberdayaan masyarakat di kawasan hutan Ketambe tidak benar-benar secara serius diaplikasikan di lapangan. Selain itu, kebijakan tentang pemanfaatan hutan yang disosialisasikan pemerintah merupakan bentuk formalitas yang bermuatan politis. Hal tersebut mendorong kurangnya kepercayaan masyarakat Ketambe pada pemerintah dalam mengurus izin pengelolaan dan penebangan hutan secara legal. Meskipun memiliki nilai tambah, masyarakat menganggap langkah-langkah pembuatan perizinan cukup sulit dan rumit. Kondisi ini mendorong masyarakat memilih untuk menebang dan menjual kayu secara ilegal.

5 | Jurnal Ilmu Sosial dan Ilmu Politik Malikussaleh (JSPM) Volume 1 Nomor 1 Periode Januari-Juni 2020 


\section{a. Toke Kayu dan Jaringannya}

Toke kayu merupakan sebutan untuk para pemilik modal dan mengendalikan beberapa eksekutor untuk kegiatan pembalakan liar. Toke kayu biasanya memiliki pengaruh yang besar dan berpendidikan tinggi di dalam masyarakat Ketambe, seperti salah seorang toke yang bernama "Nih" (nama samaran). Ia merupakan tokoh masyarakat yang dikenal sebagai perangkat desa serta anak dari seorang mantan kepala desa di salah satu desa di Kecamatan Ketambe sehingga pengaruhnya cukup besar pada masyarakat di wilayah tersebut. Dengan modal dan pengaruh yang besar, toke kayu tersebut memanfaatkan posisinya sebagai tokoh masyarakat untuk memobilisasi dan memfasilitasi masyarakat Ketambe.

Para toke kayu biasanya mempekerjakan pemuda yang telah putus sekolah yang dominan tidak memiliki pekerjaan tetap dan tidak terbatas usia. Selagi masih sanggup dan mampu untuk bekerja maka akan tetap dipekerjakan. Para anggota pembalak yang bekerja pada toke kayu biasanya sebelum melakukan aktivitas pembalakan mendengarkan instruksi dari toke kayu, jenis kayu apa saja yang dibutuhkan untuk diambil dan diproduksi serta keamanan razia dari aparat keamanan hutan sehingga mereka bisa aman dan nyaman bekerja tanpa harus khawatir akan ditangkap aparat keamanan dari pihak kepolisian kehutanan.

Hal tersebut mendorong para eksekutor pembalak liar yang berada di lapangan harus bekerjasama dan berkoordinasi dengan toke kayu sehingga aktivitas ini bisa saling menguntungkan, karena setiap akan diadakan razia oknum-oknum aparat tersebut telah menginformasikan terlebih dahulu kepada toke kayu sehingga toke kayu tersebut dapat menghentikan sementara aktivitas kegiatan pembalakan. Para toke kayu biasanya memiliki jaringan dengan oknum pemerintahan dan oknum aparat keamanan. Keterlibatan oknum pemerintah dan oknum aparat merupakan sebuah rantai dalam sistem yang terstruktur untuk melancarkan aktivitas pembalakan liar. Diperkuat oleh jaringan dan hubungan yang erat inilah kegiatan ini tetap berlangsung. Untuk mengamankan kegiatan pembalakannya, para toke kayu tersebut biasanya bekerjasama dengan oknum aparatur negara yang terlibat dalam mengamankan dan menjaga hutan, seperti oknum Dinas Kehutanan, oknum Kepala Desa, oknum Polri, dan oknum TNI dengan memberikan gratifikasi kepada mereka.

Dalam dunia perkayuan atau pembalakan, para toke kayu akan mempertahankan eksistensinya sebagai pemilik modal dan mempertahankan agar eksekutornya tetap mau bekerja kepadanya dengan cara sebelum bekerja mereka sudah diberi fasilitas seperti sepeda motor yang telah dimodifikasi serta alat pemotong kayu dan alat-alat yang diperlukan untuk kegiatan pembalakan, serta sejumlah uang untuk dipinjamkan kepada para eksekutornya dengan 
pembayaran cicil melalui hasil kerja eksekutor tersebut. Hal ini mendorong para eksekutor tetap bekerja pada toke kayu dan menjalankan tindakan sesuai perintah toke kayu tersebut. Melalui metode ini para toke kayu dapat memperhitungkan resiko dan kekuatan persaingan dalam hal produksi dan distribusi serta menjaga kapasitas usahanya agar tetap bertahan dan beroperasi secara kontinu. Kesamaan orientasi dalam meningkatkan kesejahteraan dan dorongan ekonomi dan doktrinisasi yang melandasi terbentuknya sistem dalam melakukan tindak pembalakan liar. Dengan adanya jaringan toke kayu dengan para oknum aparatur negara tersebut, memudahkan para toke kayu untuk mendistribusikan kayu tersebut secara terselubung dan sistematis.

\section{b. Pengolahan Kayu}

Usaha pengolahan kayu merupakan peluang bisnis yang sangat pontensial di Kecamatan Ketambe. Banyak usaha di luar bidang itu yang terpaksa gulung tikar karena tidak mampu bersaing dengan zaman yang penuh dengan kemajuan teknologi dan sistem informasi. Namun usaha pengolahan kayu menjadi unggulan dan banyak diminati oleh masyarakat di kawasan Ketambe. Kayu merupakan bahan baku yang banyak dan mudah untuk diperoleh di Kecamatan Ketambe, meskipun kayu tersebut ilegal, Terlebih mesin pengolahan kayu yang ada saat ini sudah sangat modern dan sangat membantu dalam pengolahan perkayuan. Industri perkayuan hingga kini masih menjadi pilihan usaha beberapa orang di kawasan Ketambe. Hal ini berpotensi menambah semaraknya pengolahan kayu sebagai bisnis yang sangat menjanjikan.

Kemudahan dalam hal produksi dikarenakan Kecamatan Ketambe cukup strategis dan mudah dijangkau sehingga mengefektifkan biaya modal. Fasilitas alat dan bahan baku, mesin kerja pengolahan kayu, seperti pemotong kayu, gelondongan, mesin ketam dan peneyerut kayu, mesin potong kecil, mesin profile, dan perkakas sudah mampu dioperasikan secara baik oleh masyarakat setempat. Demikian pula halnya dengan proses distribusi kayu, tidak terlalu sulit untuk dilakukan.

Bahan baku yang diperoleh berupa kayu diambil dari kawasan hutan lindung. Prosesnya menggunakan mesin singso sebagai alat untuk menebang dan memotong kayu sesuai ukuran yang diinginkan dan alat lainnya untuk pengangkutan seperti sepeda motor yang telah dimodifikasi baik tenaga dan suaranya agar lebih mudah mengangkut bahan baku dengan cara menyeret kayu tersebut di jalanan, tanjakan, maupun turunan menuju tempat yang diinginkan. Tempat transaksi penjualan berpindah-pindah sesuai siapa pihak yang memesan. Maka dari itu untuk memesan kayu di wilayah Kecamatan Ketambe sangatlah mudah dan dapat disediakan sesuai orderan. Hal tersebut lazim terjadi meskipun negara telah melarang adanya transaksi jual-beli berupa kayu dari kawasan hutan lindung. 
Hasilnya didistribusikan ke daerah-daerah kecamatan lain dalam bentuk kayu, tiang, dan papan yang nantinya diolah menjadi bahan kebutuhan panglong. Dari observasi peneliti, pembalak liar di Kecamatan Ketambe mendistribusikan atau memasok kayu ke kecamatan lain pada malam hari dalam jangka waktu satu kali dalam 24 jam. Seperti diutarakan oleh seorang pembalak yang bernama Tumin (47 tahun) dalam wawancara pada tanggal 26 Agustus 2020 sebagai berikut:

"Kami ke hutan untuk menebang kayu tidaklah sembarang menebang kayu, kami memulai yang pertama adalah memilih lokasi untuk menebang, sudut kemiringan tanah untuk memudahkan arah tumbangnya kayu dan mudah untuk membawa alat-alat yang kami gunakan seperti gergaji mesin dan minyak. Setelah kami rasa lokasinya cocok meski di bawah jurang namun kami kira-kira sangguplah tenaga manusia untuk memikulnya ke jalan untuk diikatkan ke sepeda motor untuk ditarik ke perkampungan/desa. Setelah kayu sampai ke desa biaya yang langsung terjual namun ada kadang keadaan pembelinya tak ada akan kami stok dulu menunggu pembeli datang ke tempat kami untuk membeli kayu tersebut." (Tumin, Kecamatan Ketambe, 26/08/2020)

Dari wawancara dengan seorang pembalak kayu di atas, peneliti dapat memahami bahwa praktik kegiatan pembalak liar dilakukan secara sistematis. Tingginya permintaan akan kebutuhan bahan baku kayu membuat kegiatan tersebut berlangsung terus menerus.

Gambar 1. Kayu Hasil Pembalakan Liar

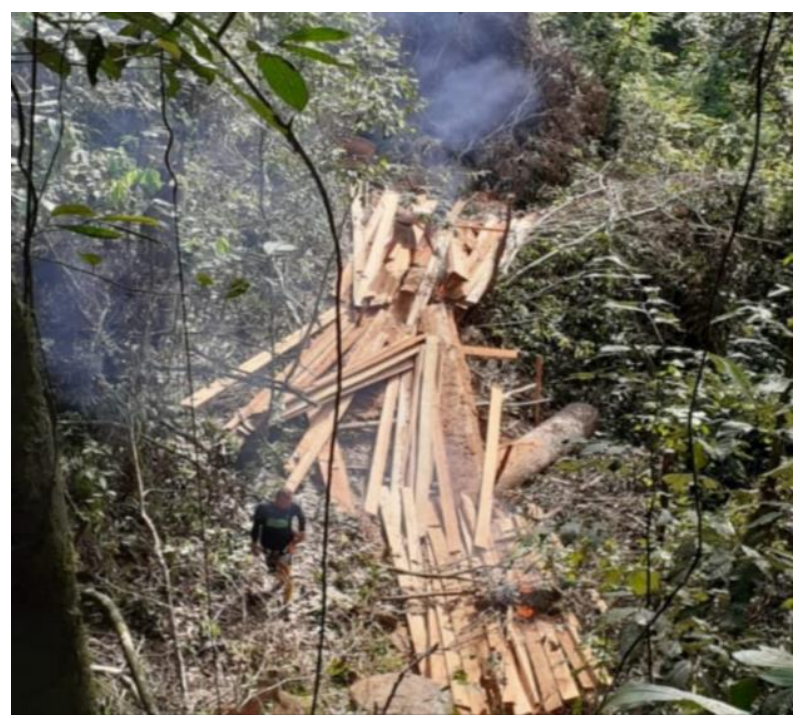

Sumber : Dokumentasi Penelitian, 2020.

Sementara itu, praktik pengangkutan kayu dilakukan pada momen khusus, seperti waktu sholat Maghrib, seperti diutarakan oleh seorang toke kayu yang bernama Suilmar (27 tahun) sebagai berikut : 
"Untuk pengangkutan kayu biasanya kami berangkat saat Maghrib karena keadaan tersebut sedang sepi kendaraan sehingga memudahkan kami menghindari aparat di pos penjagaan. Namun ketika kami lewat ditangkap kami sudah ada jaringan dari pihak-pihak tertentu untuk mengeluarkan kayu kami, tapi biasanya ketika ada razia informasi sudah sampai kepada kami sehingga operasi dan kegiatan kami hentikan untuk beberapa saat." (Suilmar, Kecamatan Ketambe, 13/08/2020)

\section{Proses Sosialisasi Habitus Pembalak Liar pada Masyarakat Ketambe}

Sosialisasi terjadi melalui interaksi individu dengan individu lainnya, kelompok dengan individu, atau kelompok dengan kelompok lainnya (Soekanto, 2012). Individu disini belajar sesuatu dari orang-orang yang dekat, seperti keluarga, teman, guru, media, dan orang-orang yang berada di lingkungannya (Astutik, 2017). Ada beberapa tahap dalam proses sosialisasi (Mead dalam Widayanti, 2008) diantaranya tahap persiapan, tahap meniru, tahap siap bertindak, dan tahap penerimaan norma kolektif.

Proses sosialisasi pembalak liar di lingkungan masyarakat Ketambe melalui beberapa tahap yang berawal dari meniru dimana seorang individu sejak usia anak-anak sudah diajak ke hutan oleh keluarga atau kerabat dekatnya untuk menyaksikan aktivitas pembalakan, meskipun belum turut serta melakukan aktivitas tersebut. Namun anak-anak ini sudah dapat meniru tindakan-tindakan sebagaimana layaknya pembalak. Ketika mereka beranjak pada usia remaja, pada tahap ini mereka telah siap bertindak untuk turut serta dalam melakukan aktivitas pembalakan liar. Mereka telah menentukan tindakan-tindakan yang akan dilakukannya sebagai seorang pembalak pemula. Kemudian pada tahap menentukan peran, dalam tahap ini mereka sudah dewasa dan dapat menentukan peran di kalangan para pembalak berdasarkan pengalaman yang telah dilaluinya.

Media sosialisasi memiliki peran yang sangat penting dalam mempengaruhi, melaksanakan, atau melakukan tindakan pembalakan liar. Hal ini memungkinkan masyarakat Ketambe menerima proses sosialisasi tentang bagaimana mencari pekerjaan yang relatif instan dan menghasilkan uang dengan cepat seperti ikut serta menjadi seorang pembalak liar. Ada beberapa agen utama dalam proses sosialisasi terhadap pembalak liar, yaitu:

Pertama, keluarga. Keluarga merupakan agen sosialisasi pertama yang meliputi orangorang terdekatnya seperti: ayah, ibu, saudara kandung, saudara angkat, dan keluarga lain yang tinggal secara bersama-sama dalam satu rumah. Dalam lingkungan keluarga anak mengenal dunia sekitarnya dan aktivitas pembalakan liar yang dilakukan oleh keluarganya sehari-hari. Kedua, teman bermain. Teman bermain dialami seorang anak setelah belajar berinteraksi dengan orangorang yang sederajat karena mereka seusia atau sebaya. Dalam sosialisasi seorang anak pembalak

9 | Jurnal Ilmu Sosial dan Ilmu Politik Malikussaleh (JSPM) Volume 1 Nomor 1 Periode Januari-Juni 2020 
liar akan menceritakan tindakan pembalakan atau bahkan menirukan tindakan sebagai pembalak tersebut yang ia saksikan dengan teman sebayanya.

Proses sosialisasi bertujuan untuk mempelajari nilai, norma sosial, membentuk perilaku, dan kepribadian seorang individu di dalam suatu masyarakat dan membentuk pola perilaku individu, menjaga keteraturan hidup dalam masyarakat, serta menjaga integrasi kelompok di dalam masyarakat. Proses sosialisasi pada pembalak liar tersebut sangat berpengaruh pada mental dan psikis seseorang. Sosialisasi pembalak liar diajarkan untuk menanamkan ide aspirasi atau cita-cita bersama sehingga seorang individu akan bertindak sesuai dengan lingkungan inginkan padanya. Hal ini seperti yang terjadi di lingkungan yang didominasi oleh para pembalak liar sehingga individu akan terpengaruh menjadi seorang pembalak. Namun melalui proses sosialisasi para pembalak tersebut terbentuk mental dan perilaku sebagai pembalak yang menentukan perannya di kalangan pembalak liar.

\section{a. Proses Internalisasi}

Proses internalisasi dimulai dengan seseorang mempelajari suatu norma. Kemudian individu menjalani proses memahami mengapa mereka bernilai atau mengapa mereka masuk akal hingga akhirnya mereka menerima norma sebagai sudut pandang mereka sendiri. Norma yang diinternalisasikan dikatakan bagian dari kepribadian individu dan dapat ditunjukkan sebagai suatu tindakan moral seseorang. Namun, ada juga perbedaan antara komitmen internal terhadap norma dan apa yang ditunjukkan secara eksternal. Satu hal yang dapat mempengaruhi apa yang diinternalisasikan seseorang adalah panutan. Model ini sering digunakan dalam mempercepat suatu proses sosialisasi. Internalisasi membantu seseorang menentukan siapa mereka dan menciptakan identitas dan nilai mereka sendiri dalam masyarakat yang telah menciptakan seperangkat norma, nilai, dan suatu praktik di dalam masyarakat. Proses internalisasi penanaman perilaku, sikap, dan nilai pada seorang pembalak liar yang diperolehnya melalui pembinaan, belajar, dan bimbingan. Harapannya apa yang didapatkannya dan dilakukannya sesuai dengan keinginan dan harapan di kalangan pembalak liar. Internalisasi pada seorang pembalak liar dilakukan berkali-kali dengan cara meniru tindakan seorang mentor dalam hal pembalakan. Alhasil menjadi suatu pola yang normal yang mengatur tindakannya, dibudayakan, maka dari situlah terjadi internalisasi praktik pembalakan. Berikut tahapan dari proses internalisasi pada pelaku pembalak liar pada masyarakat Ketambe.

Pertama, tahap transfer nilai. Pada tahap ini terjadi komunikasi secara verbal, transfer ini sifatnya hanya pemindahan suatu pengetahuan dari pendidik ke peserta didiknya. Nilai-nilai yang 
diberikan masih berada pada ranah kognitif. Pada tahap ini pembalak liar menerima masukan melalui saran-saran komunikasi yang disampaikan oleh para keluarga atau kerabat pembalak liar agar para pembalak liar mengetahui nilai-nilai yang pro dan kontra pada tindakan-tindakan aktivitas pembalakan. Pada tahapan ini juga disebut seorang pembalak mulai memahami dan menumbuhkan sikap mengenai makna atau arahan dari keluarga atau pembalak yang lebih berpengalaman sehingga mengurangi tingkat resiko atau kesalahan yang fatal pada aktivitas pembalakan liar. Kedua, tahap transaksi nilai. Pada tahap ini proses yang dilakukan oleh pembalak dengan cara komunikasi timbal balik sehingga memungkinkan informasi nilai yang didapat para pelaku pembalak liar dapat dipahami oleh rekan kerja sehingga mereka dapat merespon nilai yang sama. Ketiga, tahap tran-internalisasi. Tahap ini dilakukan dengan sikap, mental, dan kepribadian para pembalak. Jadi pada tahap ini pembalak berperan secara aktif dalam mengajarkan nilai-nilai dan membangun karakter pada pembalak lainnya yaitu seperti pengetahuan tentang moral ketika berada di kawasan praktik pembalakan seperti tidak boleh sombong (takabur) di dalam hutan dengan perasaan yang selalu waspada ketika melakukan aktivitas pembalakan.

\section{b. Proses Inkulturasi}

Proses inkulturasi merupakan suatu proses yang mempelajari suatu nilai dan norma kebudayaan. Seorang individu mempelajari dan menyesuaikan alam pikirannya serta sikapnya dengan adat-istiadat, sistem norma, dan peraturan yang hidup di dalam kebudayaannya. Proses pembudayaan merupakan panduan dari komplek pengetahuan, nilai-nilai, gagasan-gagasan pokok dan baku, serta keyakinan, dan nilai-nilai yang dimiliki manusia sebagai makhluk sosial yang isinya merupakan seperangkat model pengetahuan atau sistem makna yang terjalin secara komprehensif dalam simbol-simbol yang ditransmisi secara historis. Pengetahuan ini juga digunakan sebagai cara selektif oleh warga masyarakat pendukungnya untuk berkomunikasi dan berinteraksi, melestarikan dan menghubungkan pengetahuan dan sikap serta cara bertindak dalam rangka memenuhi kebutuhan hidupnya. Proses sosialisasi enkulturasi pada para pembalak liar di dalam masyarakat Ketambe melalui suatu kebiasaan tindakan pembalakan dengan terus-menerus ditanamkan dari generasi ke generasi sehingga lambat laun akan menjadi kebiasaan yang melekat dan membudaya pada keluarga atau kerabat para pembalak liar tersebut.

Berdasarkan uraian proses sosialisasi di atas maka peneliti menganalisis bahwa sosialisasi merupakan sesuatu kesadaran mental yang dihasilkan melalui hasil transfer pengalaman empiris sehingga melalui transfer pengalaman tersebut maka akan menghasilkan suatu tindakan-tindakan tertentu. Sosialisasi pembalak liar di kawasan Ketambe berawal dari diperdengarkan, yaitu transfer 
melalui memberi pemahaman pada calon pembalak liar. Mereka diberikan cara tentang bagaimana proses untuk membalak yang benar. Berikutnya diperlihatkan, yaitu proses transformasi yang langsung disaksikan tentang cara melakukan pembalakan yang benar. Terakhir diajarkan serta disuruh untuk melakukan tindakan, yaitu ajaran tersebut adalah proses akhir untuk melihat bagaimana hasil yang baik dan sekaligus menjadi suatu tindakan kesadaran mental.

Berdasarkan wawancara dengan salah senebang penebang kayu (penabah kayu) yang bernama Kamal (54 tahun), sosialisasi habitus di Kecamatan Ketambe mulai diajarkan di dalam lingkungan keluarga, sebagaimana keterangan berikut:

“Awalnya aku, urusan kayu adalah pekerjaan sampinganku... dengan orang tua dahulu kami urusan kayu hampir semua teman sebayaku diajarkan urusan kayu... sejak kami anak-anak sudah diajak ke hutan urusan kayu. Dahulu urusan kayu bukan untuk dijual melainkan untuk keperluan rumah kami dan fasilitas desa kami... kalau untuk kebutuhan ekonomi pangan, kami bercocok tanam dengan padi dan memelihara beberapa ternak. Namun untuk sekarang kami mulai tergantung urusan kayu karena lebih mudah menurutku urusan kayu yang diajarkan oleh orang tua kami dahulu... untuk mencari nafkah rumah tangga kami”. (Kamal, Kecamatan Ketambe, 10/08/2020)

Berdasarkan hasil wawancara di atas, peneliti dapat memahami bahwasanya proses sosialisasi habitus di kalangan keluarga pembalak liar sudah diajarkan sejak mereka kecil dan praktik pembalakan liar dimotori motif instan dalam rangka memenuhi kebutuhan ekonomi. Namun pada awalnya proses pemanfaatan kayu yang diajarkan oleh orang tua di lingkungan tersebut bukan untuk barang komoditi melainkan untuk kebutuhan mereka seperti rumah, jembatan, balai desa, dan lain sebagainya. Dengan adanya proses sosialisasi habitus sebagai pembalak liar, masyarakat Ketambe terperangkap di dalam dunia hitam pembalakan liar yang berlanjut ke generasi berikutnya.

Gambar 2. Proses Pengorderan Kayu secara Langsung di Hutan



Sumber: Dokumentasi Penelitian, 2020.

12 Jurnal Ilmu Sosial dan Ilmu Politik Malikussaleh (JSPM) Volume 1 Nomor 1 Periode Januari-Juni 2020 
Penebangan pohon dan pengangkutan secara liar oleh masyarakat di wilayah Kecamatan Ketambe dilakukan untuk memenuhi permintaan pasokan bahan baku kayu dalam rangka memenuhi berbagai keperluan masyarakat dan proyek kontraktor. Masyarakat menilai usaha di bidang perkayuan bersifat instan dalam memenuhi kebutuhan ekonomi mereka, yaitu dapat memberikan penghasilan secara langsung dan lebih besar dalam waktu yang singkat dibandingkan jenis pekerjaan lainnya. Seperti diutarakan seorang pengangkut kayu yang bernama Ramzani (25 tahun):

"Kegiatan pengangkutan kayu diajarkan kepada kami semenjak kami masih remaja, karena kebanyakan daripada kami putus sekolah karena faktor lokasi nan jauh dan kurangnya tenaga pengajar, dan faktor ekonomi. Hal tersebut menyebabkan kami belajar mengikuti kegiatan orang tua untuk menjadikan kami berurusan dengan perkayuan. Awalnya orang tua kami kebanyakan tukang menebang kayu dan kami belajar berawal dari tukang kuli angkat kayu dari dalam hutan ke tepi jalan sehingga memudahkan untuk pengangkutan ke tempat penampungan kayu tersebut sehingga dapat diperjual belikan atau diolah menjadi kebutuhan panglong". (Ramzani, Kecamatan Ketambe, 10/08/2020)

Dari wawancara diatas dapat dipahami bahwa kegiatan pengangkutan kayu diajarkan dan disosiolisasikan oleh kerabat terdekat semenjak individu memasuki usia remaja dan ditambah kondisi putus sekolah sehingga individu tersebut lebih mudah untuk diajak menjadi seorang pembalak liar di hutan wilayah Ketambe. Kemudian proses sosialisasi habitus berjalan sesuai dengan kebiasaan. Legalisasi tindakan secara mental dan psikis membangun pemahaman dalam masyarakat Ketambe bahwa hal tersebut sebagai sesuatu yang lazim dilakukan dalam lingkungannya meskipun masyarakat tersebut mengetahui dampak dari kegiatan tersebut terhadap kerusakan alam dan krisis sumber daya air pada musim kemarau. Seperti yang diutarakan oleh toke kayu yang bernama 'Nih" (nama samaran) (34 tahun) berikut ini:

"Saat ini proses untuk urusan kayu lebih mudah dan lebih menjanjikan ketimbang kerjaan lainnya sehingga masyarakat lebih tertarik walaupun pekerjaan tersebut penuh dengan resiko kematian dan kecelakaan kerja... meskipun pekerjaan tersebut masyarakat mengetahui akibatnya berdampak pada banjir bandang”. (Nih, Kecamatan Ketambe, 11/08/2020)

Selanjutnya dari hasil wawancara dengan seorang toke kayu yang bernama Gunawan dapat dipahami bahwa kegiatan pembalakan liar dilatarbelakangi oleh sulitnya mencari pekerjaan yang layak ditambah keinginan masyarakat mendapatkan sumber daya secara instan menjadikan kegiatan pembalakan liar menjadi pilihan yang sangat rasional. Proses sosialisasi pekerjaan ini sangat mudah karena kebanyakan pemuda memiliki ketertarikan karena secara ekonomi usaha ini sangat menggiurkan meskipun mereka sudah mengetahui dampak dan resiko pekerjaan tersebut 
sangatlah tinggi. Berikut ini adalah gambar proses penarikan kayu (ojek kayu) yang berada di wilayah Ketambe:

\section{Gambar 3. Proses Pengojek Kayu}

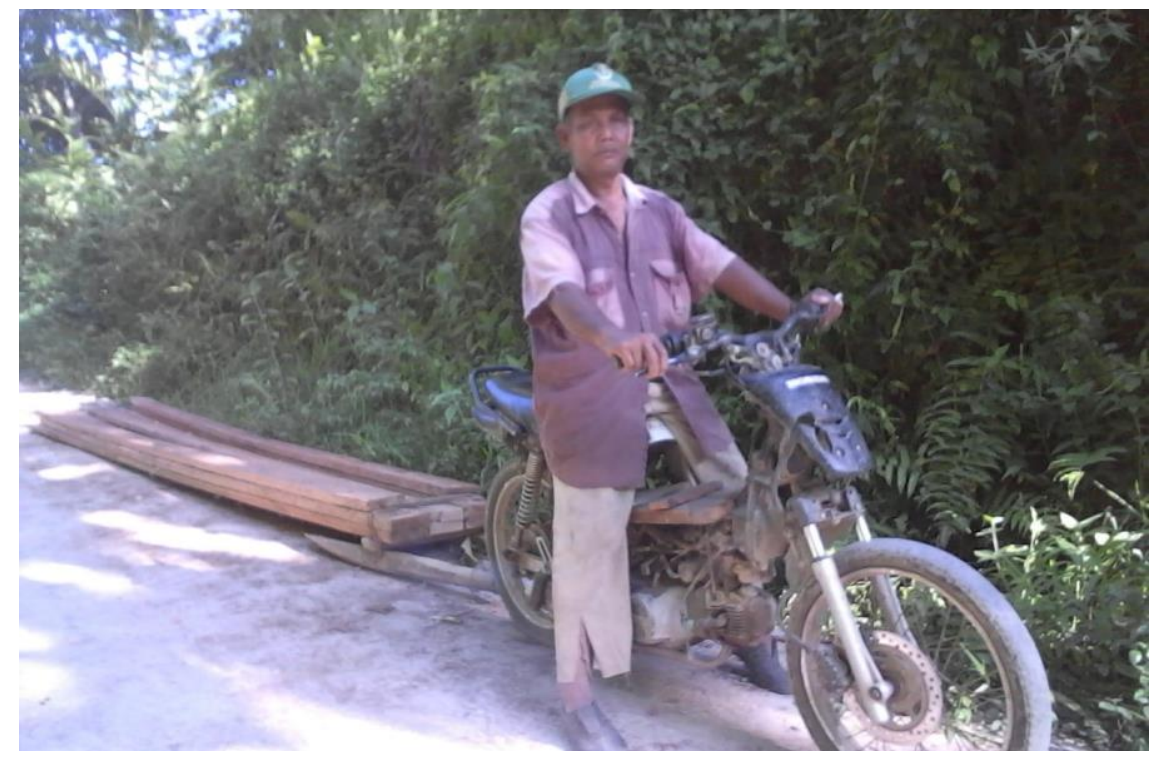

Sumber: Dokumentasi Penelitian, 2020.

Dalam rangka memudahkan proses sosialisasi habitus dalam keluarga pembalak, para orang tua dan kerabat mulai melibatkan seorang dari masa remaja terkhusus pada mereka yang sudah putus sekolah. Praktik pembalakan liar dapat terinternalisasi dan terinkulturasi dengan baik bukan hanya karena diajarkan oleh keluarga dan masyarakat, namun juga oleh keadaan. Seperti diutarakan oleh seorang pengojek kayu yang bernama Ilham Dayu (27 tahun) dalam petikan wawancara berikut:

"Pengojek kayu bukan lah pekerjaan pilihanku, namun keadaan memaksaku untuk menjadi seorang pengojek kayu. Dulu aku bekerja sebagai petani di sawah... menanam padi, kacang-kacangan. Setelah lahan pertanianku dibawa oleh arus sungai (abrasi) sehingga hanyut, lahan kami tak bisa terpakai lagi. Menurutku urusan kayu sulit untuk dicegah karena sudah menjadi kebiasaan dan menjadi kebutuhan hidup sehingga kebanyakan masyarakat mengijinkan dan mendukung kegiatan tersebut dikarenakan setelah orang bekerja sebagai pembalak pencurian berkurang di wilayah kecamatan Ketambe". (Ilham Dayu, Kecamatan Ketambe, 08/08/2020)

Keterangan di atas cukup menarik untuk disimak karena ternyata keberadaan aktivitas pembalakan liar dianggap fungsional oleh masyarakat setempat dalam mengurangi tingkat pencurian di wilayah Ketambe. 
Gambar 4. Abrasi Sungai Sawah Yang Telah Menjadi Aliran Sungai

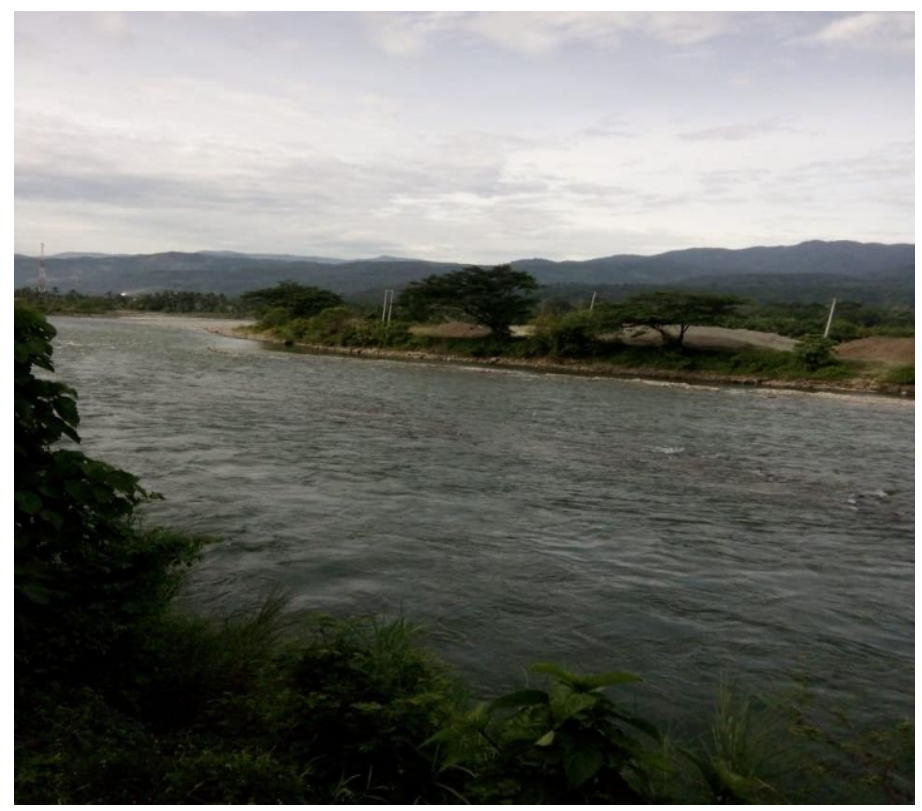

Sumber : Dokumentasi Penelitian, 2020

Proses sosialisasi habitus pada pembalak dipengaruhi oleh suatu sistem yang telah dibangun oleh cara pandang pragmatisme. Masyarakat akan dijanjikan sesuatu yang bersifat materi yang dulunya tidak mereka butuhkan. Namun pada saat ini mereka memiliki ketergantungan sumber daya meskipun proses tersebut banyak merugikan lingkungan alam, khususnya hutan. Demonstrasi kepemilikan materi dilakukan oleh beberapa remaja pembalak liar dengan cara memamerkan benda-benda seperti handphone bermerek dan sepeda motor hasil dari kerja sebagai pembalak liar yang akan membuat para remaja lainnya tertarik dan ingin mengikuti profesi tersebut meski tanpa paksaan.

\section{c. Proses Sosialisasi Habitus Turun-Temurun Pembalak Liar}

Dalam hal ini, proses sosialisasi habitus secara turun-temurun di kalangan pembalak liar merupakan kegiatan dari masa lalu. Kemudian habitus tersebut menjadi tradisi yang sudah ada sampai saat ini. Sosialisasi dari generasi ke generasi melibatkan pihak-pihak yang menjalankan aktivitas pembalakan liar. Tradisi turun-temurun dengan membagi peran atau pemberian hak dan kewajiban untuk menjalankan sesuatu akan menciptakan keberlangsungan sebuah pekerjaan dalam artian di sini sebuah produksi kayu meskipun dengan cara tidak sah secara hukum negara. Tindakan pembalakan liar telah disosialisasikan secara turun-temurun sehingga masih bertahan hingga kini 
dilihat dari awal tahun 1980-an berdasarkan hasil wawancara sebelumnya. Namun sekarang sudah banyak mengalami pertukaran orang (aktor) yang menjalankan kegiatan tersebut.

Menurut wawancara dengan seorang mantan pembalak liar yang sudah pensiun yang bernama Pak Saharuddin (67 tahun):

"Kegiatan menebang kayu ini sudah turun-temurun diajarkan meski pada awalnya tidak untuk diperjual-belikan, karena sejak kami anak-anak sudah dibawa oleh orang tua kami ke hutan, sehingga di hutan kami diajarkan bagaimana cara untuk menebang kayu yang benar, nama-nama kayu yang bisa dipakai untuk tahan lama, untuk mengetahui kemana arah tumbangnya melalui sudut kemiringan kayu tersebut. Dimana kami melihat lokasi untuk memudahkan kami untuk mengolahnya menjadi kebutuhan yang kami perlukan, sehingga saya juga mengajarkan apa yang pernah diajarkan oleh orang tua ke anak-anakku. Namun bedanya orang tua kami mengajarkan cara menebang kayu... dulu kami diajarkan menggunakan kapak... namun sekarang kami pakai gergaji mesin. Namun cara penebangan dan pemilihan pohonnya masih sama dengan dulu." (Saharauddin, Kecamatan Ketambe, $10 / 08 / 2020)$

Berdasarkan hasil wawancara tersebut diketahui bahwa sekarang profesi informan sudah digantikan oleh anaknya. Menurut informan proses sosialisasi masih tetap dilakukan hingga saat ini. Hal tersebut diajarkan dengan mengajak anak-anaknya ke hutan untuk menyaksikan bagaimana proses menebang kayu, memilih kayu yang dapat bertahan lama dan bagaimana tata cara untuk menebang kayu yang baik sehingga dapat diolah dengan mudah. Proses sosialisasi habitus pembalak dilakukan secara turun-temurun dengan alat yang digunakan mengikuti proses perkembangan zaman sehingga proses pembalakan tersebut menjadi lebih cepat dan lebih mudah. Namun mekanisme dalam pemilihan kayu dan penebangannya masih sama dengan yang diajarkan oleh keluarga atau kerabat terdekat pembalak tersebut. Dari hasil observasi peneliti menganalisis bahwa proses sosialisasi pembalak liar tersebut yang telah banyak dipengaruhi oleh modernisasi dan globalisasi. Hal ini sangat efektif dalam membantu memudahkan pekerjaan mereka.

Lingkungan sekitar sangat besar pengaruhnya terhadap individu sebab dalam kehidupan sehari-hari individu lebih banyak bergaul di tempat ia tinggal. Lingkungan membentuk kepribadian dan habitus sebagai pembalak karena di dalam pergaulan sehari-hari seorang individu akan menyesuaikan dengan kebiasaan lingkungannya. Apabila seorang individu bertempat tinggal di suatu lingkungan yang temannya banyak para pelaku pembalak, kemungkinan besar hal tersebut akan mempengaruhinya. Pendidikan di dalam masyarakat adalah pendidikan yang diselenggarakan di luar keluarga dan sekolah, dan merupakan suatu pengharusan akan kehadirannya untuk menentukan peran, terutama dalam memberikan pengetahuan dan keterampilan khusus secara praktis, yang secara langsung berpengaruh bagi karakternya di dalam masyarakat.

16 Jurnal Ilmu Sosial dan Ilmu Politik Malikussaleh (JSPM) Volume 1 Nomor 1 Periode Januari-Juni 2020 
Salah satu dampak dari sosialisasi yang sangat berpengaruh yaitu habitus. Kebiasaan pembalakan liar terbentuk melalui proses konstruksi oleh lingkungan di sekitarnya sehingga menjadi suatu kesadaran mental. Hal tersebut secara langsung terinternalisasi pada diri mereka dan menjadi hal biasa di lingkungan tersebut ditambah dengan dukungan lingkungan dalam memudahkan generasi berikutnya untuk membentuk habitus pembalak baru di masyarakat Ketambe.

\section{Motivasi Melakukan Pembalakan Liar}

\section{a. Pandangan Ideologis Memenuhi Kebutuhan Hidup}

Masyarakat Ketambe yang terlibat dalam kegiatan pembalakan liar dilandasi oleh pandangan pragmatisme tentang bagaimana memperoleh suatu keuntungan ekonomi dalam waktu yang cukup singkat. Pandangan tersebut sangat dipengaruhi oleh desakan kebutuhan hidup sehingga menjadi pembalak liar dianggap sebagai pilihan yang rasional. Dengan cara pandang demikian akan menjadi tindakan yang berpolarisasi kepada suatu kebiasaan yang disosialisasikan melalui pendengaran, penglihatan, dan tindakan.

Para pelaku yang terlibat dalam aktivitas pembalakan liar berusaha untuk mempresentasikan identitas kelompok dan membuat area dalam tempat singgahnya, seperti di warung kopi dekat dengan lokasi pembalakan liar, sehingga aktivitas berkumpul para pembalak liar dapat dilakukan dalam suasana akrab, santai, dan kekeluargaan. Keberadaan identitas kelompok pembalak liar pada area warung kopi tersebut dalam rangka memupuk kebersamaan yang didasari oleh adanya ideologi pragmatisme yang didesain oleh para actor pembalak di wilayah tersebut. Dengan demikian, identitas kelompok pembalak direpresentasikan melalui pragmatisme yang dijadikan pendekatan atau konsep citra dalam bentuk desain.

Meskipun aktivitas pembalakan liar dianggap menyimpang dalam kebanyakan masyarakat karena berdampak negatif terhadap alam, namun hal itu tidak menyurutkan aktivitas pembalakan liar di Kecamatan Ketambe karena mereka telah didoktrin semenjak usia muda bahwa menjadi seorang pembalak adalah pekerjaan yang menjanjikan, bersifat instan, dan tak perlu waktu lama untuk menghasilkan uang atau materi. Hal tersebut didorong oleh kondisi era globalisasi yang serba praktis, yang mendorong mereka untuk bekerja sebagai pembalak liar. Meskipun menjadi pelaku pembalak liar bukan satu-satunya pilihan yang tersedia untuk memenuhi kebutuhan ekonomi, namun pekerjaan sebagai pembalak liar menjadi sangat diminati oleh kebanyakan masyarakat, terutama pemuda di wilayah Ketambe Kabupaten Aceh Tenggara. 


\section{b. Motivasi dan Tindakan Sosial}

Motivasi merupakan keinginan yang timbul pada diri seseorang secara sadar maupun tidak sadar dengan tujuan tertentu sehingga mengakibatkan seseorang atau kelompok orang tergerak melakukan sesuatu karena ingin mencapai suatu tujuan yang dikehendaki. Apabila dikaitkan dengan pembalakan liar, maka motivasi pembalak liar adalah dorongan dari cara pandang pragmatis tentang memperoleh keuntungan ekonomi dalam waktu yang cukup sehingga berkeinginan memiliki barang-barang tertentu yang menyebabkan seseorang melakukan aktivitas pembalakan. Keinginan tersebut sangat menentukan suatu hasil yang dicapainya. Bahkan ada yang menjadi iri terhadap prestasi yang diraih oleh tetangga atau temannya sebagai motivasi untuk terus meningkatkan kinerja dalam kegiatan pembalakan untuk meraih hasil yang lebih baik daripada mereka.

Selain itu, faktor pendorong lainnya adalah modernisasi dan globalisasi (Rosana, 2011; Sztompka, 2014) sehingga mereka terpengaruh gaya hidup yang mahal dan ingin memiliki barangbarang mewah seperti yang dimiliki oleh orang lain yang disaksikannya melalui media. Hal itu menuntun mereka agar bekerja sebagai pembalak liar yang lebih rajin dan giat sehingga hasilnya dapat memenuhi berbagai macam keinginan tersebut. Jadi tindakan pembalakan liar didasari oleh motivasi para pembalak yang mendorong mereka untuk bertindak sehingga melahirkan suatu tindakan sosial.

Tindakan sosial merupakan proses aktor terlibat dalam pengambilan-pengambilan keputusan subjektif tentang sarana dan cara untuk mendapatkan tujuan tertentu sehingga tindakan tersebut mengenai jenis perilaku manusia, yang ditujukan kepada perilaku orang lain. Tindakan sosial seluruh perilaku manusia yang memiliki arti subjektif dari yang melakukannya, baik terbuka maupun tertutup, yang diutarakan secara lahir maupun diam-diam, yang oleh pelakunya diarahkan pada tujuannya (Muhlis \& Norkholis, 2016). Seperti tindakan praktik pembalakan liar bukanlah

perilaku yang kebetulan, tetapi memiliki pola, struktur, dan makna tertentu sehingga dilakukan secara terus-menerus.

Sosialisasi habitus berfokus pada praktik yang terlihat pada hasil dari hubungan dialektis antara struktur dan agensi. Habitus merupakan struktur-struktur mental atau kongnitif "melalui mana orang berurusan dengan dunia sosial. Seseorang dikaruniai serangkaian skema yang diinternalisasikan. Melalui itu mereka bisa merasakan, mengerti, mengapresiasi, dan mengevaluasi dunia sosial secara dialektis.

Habitus pembalakan liar yang terjadi di Kecamatan Ketambe Kabupaten Aceh Tenggara merupakan produk sosialisasi yang diinternalisasikan melalui struktur-struktur sosial di Kecamatan 
Ketambe. Habitus bervariasi tergantung pada hakikat posisi seseorang di lingkungan tersebut, atau tidak setiap orang mempunyai habitus yang sama. Habitus yang tertanam pada individu tertentu diperoleh secara historis dalam kehidupan di lingkungannya.

Bourdieu menggambarkan habitus sebagai dialektika struktur kognitif yang didalamnya berisi nilai-nilai sosial budaya yang memberi arahan untuk bertindak bagi aktor didalam suatu ranah. Seperti pada masyarakat Ketambe, dengan meyakini tindakan pembalakan liar bernilai ekonomi dan efektif untuk mensejahterakan masyarakat mengarahkan mereka untuk bertindak sebagai pembalak liar. Praktik habitus diciptakan dari pengalaman empiris sehingga membentuk karakter pada masyarakat. Di sisi lain lingkungan sosial yang diciptakan sebagai hasil praktik suatu tindakan seperti tindakan pembalak liar membentuk habitus yang akan menjadi polarisasi tindakan. Sebaliknya habitus membantu mempersatukan maupun membangkitkan praktik tindakan pembalak liar. Habitus juga merupakan struktur yang diinternalisasikan yang membatasi pemikiran dan pemilihan tindakan.

Tindakan sosial tersebut sangat berpengaruh pada individu di lingkungan pembalak liar dan akan bersifat membatin atau bersifat subjektif yang berpengaruh pada situasi tertentu. Bahkan terkadang tindakan dapat berulang kembali dengan sengaja sebagai akibat dari pengaruh situasi yang serupa atau berupa persetujuan secara pasif di dalam suatu masyarakat tertentu. Berdasarkan pengertian di atas, tindakan yang berhubungan dengan penelitian ini adalah tindakan rasionalitas instrumental dan tindakan tradisional (Muhlis \& Norkholis, 2016). Tindakan tersebut dilakukan seseorang atas dasar pertimbangan dan pilihan yang sadar dengan tujuan tindakan ketersediaan alat untuk mencapainya dan mesti diajarkan secara turun-temurun.

\section{c. Lapangan Pekerjaan Terbatas}

Lapangan pekerjaan yang tersedia di kawasan Ketambe saat ini masih terbatas sehingga belum bisa menandingi jumlah pertumbuhan angkatan kerja di Kecamatan Ketambe. Pendidikan dan keterampilan yang sangat rendah menjadi salah satu pemicu yang mendorong masyarakat sulit untuk mendapatkan pekerjaan yang layak. Karena untuk mendapatkan pekerjaan yang layak harus memiliki pendidikan dan keterampilan yang bagus, sehingga permintaan dan penawaran (pasar) tenaga kerja di daerah Ketambe tidak seimbang.

Lapangan pekerjaan yang layak sangat terbatas sehingga tidak mampu menyerap para pekerja yang produktif yang setiap tahun jumlahnya terus bertambah di Kecamatan Ketambe. Tingginya tingkat pengangguran menimbulkan berbagai masalah mulai dari aspek ekonomi hingga aspek sosial seperti kemiskinan. Peluang pekerjaan di wilayah Ketambe berbeda dengan di wilayah 
kota, apalagi kawasan Ketambe terletak di lereng gunung dan jauh dari kawasan industri. Kebijakan pemerintah untuk mengatasi jumlah pengangguran belum maksimal. Selama ini hanya dilakukan pelatihan UKM untuk angkatan kerja dan penyuluhan kepada petani. Lapangan pekerjaan yang terbatas tersebut disertai kemajuan modernisasi dan globalisasi sehingga pada angkatan kerja tersebut muncul pandangan pragmatis dengan bekerja untuk memperoleh hasil secara cepat atau instan.

Dengan cara pandang tersebut maka pekerjaan yang sesuai untuk mereka menjadi sangat terbatas. Sementara menjadi seorang petani sudah dianggap pekerjaan yang tidak sesuai dengan mereka karena memerlukan proses yang panjang. Alhasil beberapa dari mereka mencari lapangan pekerjaan yang sesuai, ada yang akhirnya memilih bekerja ke luar negeri sebagai tenaga kerja Indonesia (TKI), tetapi kebanyakan dari masyarakat Ketambe tersebut memilih bekerja sebagai pembalak liar.

Berdasarkan uraian di atas peneliti menganalisis bahwa banyak dari kehidupan manusia baik secara sosial maupun ekonomi melakukan suatu tindakan berdasarkan motif. Motif yang mendorong masyarakat untuk tetap melakukan tindakan pembalakan liar adalah cara pandang pragmatisme tentang memperoleh keuntungan ekonomi dalam waktu yang singkat ditambah dengan motivasi lingkungan yang ada pada masyarakat Ketambe.

Meskipun pekerjaan terbatas bagi kebanyakan masyarakat Ketambe sehingga memilih bekerja sebagai pembalak liar, namun ada sebagian masyarakat yang memilih tidak terlibat dalam aktivitas pembalakan liar. Mereka berprofesi sebagai petani komoditi seperti padi, jagung, kopi, karet, sere wangi, nilam dan sebagainya. Mereka sadar akan pentingnya keberlangsungan hutan karena penebangan hutan semakin luas akan mengganggu habitat satwa seperti babi, monyet, beruang, dan harimau yang akan menjadi hama bagi produksi pertanian mereka serta mereka penuh dengan rasa waspada akan keselamatan dari hewan buas ditambah lagi dengan bencana banjir yang akan merusak lahan pertanian mereka. Hal tersebut mendorong sebagian masyarakat yang tidak terlibat dalam pembalakan liar untuk menanam kembali berbagai jenis pohon walaupun dalam jumlah kecil.

Meskipun sebagian masyarakat yang tidak terlibat dalam pembalakan liar sadar akan pentingnya keberlangsungan hutan, namun mereka enggan untuk mencegah para pelaku pembalakan liar karena mereka merasa tidak ada wewenang dan takut dinilai mengganggu pekerjaan orang yang akan berakibat dikucilkan dalam prosesi adat. Contoh seperti seorang yang sadar akan pentingnya keberlangsungan hutan sehingga mencegah para pembalak liar untuk berhenti maka masyarakat sekitar tempat tinggalnya tidak akan mau mengikuti prosesi adat baik 
berupa perkawinan, khitanan, maupun prosesi adat kematian. Hal ini menjadi tantangan tersendiri bagi masyarakat yang sadar akan pentingnya keberlangsungan hutan. Alhasil mereka hanya memilih fokus melakukan pekerjaan dan menanam kembali berbagai jenis pohon meskipun mereka harus bungkam melihat tindakan pembalakan liar di wilayah Ketambe.

\section{KESIMPULAN}

Praktik pembalakan liar di Kecamatan Ketambe Kabupaten Aceh Tenggara dilakukan secara sistematis oleh para toke kayu yang memiliki modal dan posisi yang strategis sebagai tokoh masyarakat. Memiliki relasi dengan oknum aparatur negara dengan memberikan gratifikasi menjaga keberlangsungan usaha dalam bidang penjarahan hutan. Para toke tersebut memanfaatkan posisinya sebagai tokoh masyarakat dengan memberi kepercayaan pada eksekutor pembalak dilengkapi dengan fasilitas dan sejumlah uang pinjaman kepada eksekutor tersebut. Melalui metode itu bisnis haramnya tetap bertahan.

Sosialisasi habitus pembalak liar pada masyarakat Ketambe melalui transformasi hasil dari pengalaman empiris dengan cara diperdengarkan, diperlihatkan, dan diajarkan untuk bertindak sehingga muncul pemahaman agar bisa bertahan hidup maka mereka harus merambah kayu. Mereka kemudian diperlihatkan secara langsung bagaimana proses untuk menjadi pembalak serta diajarkan untuk terlibat secara langsung atau bertindak. Tindakan yang disosialisasikan tersebut menjadi suatu kesadaran mental sehingga terpolarisasi serta menjadi kebiasaan untuk bertindak sebagai pembalak liar sebagai hasil dari transformasi habitus.

Motif yang mendorong masyarakat Ketambe untuk tetap melakukan tindakan pembalakan liar dipengaruhi oleh cara pandang pragmatisme, yaitu tentang memperoleh keuntungan ekonomi dalam waktu singkat. Hal ini diperkuat oleh norma di lingkungan pembalak, pendidikan dan keterampilan yang rendah, dan minimnya lapangan pekerjaan sehingga membuat praktik pembalakan liar menjadi pilihan profesi bagi masyarakat Ketambe.

\section{DAFTAR PUSTAKA}

Aksan, S. P. H. (2016). Pembentukan Habitus Baru Mahasiswa Perantauan Sumbawa di Surabaya (Studi tentang Bentuk Adaptasi dan Bentuk Habitus Baru Mahasiswa Sumbawa di Surabaya). Jurnal Paradigma, 4(1), 1-8.

Astutik, D. (2017). Telaah Kritis Gagasan Sosialisasi Mead: Self, Mind, Society. Jurnal Pendidikan Sosiologi dan Antropologi, 1(1), 61-79.

21 Jurnal Ilmu Sosial dan Ilmu Politik Malikussaleh (JSPM) Volume 1 Nomor 1 Periode Januari-Juni 2020 
Fithri, E. \& Handoyo, P. (2015). Habitus Dugem Kelompok Youngstar sebagai Ritus Modernitas di Surabaya. Jurnal Paradigma, 3(1).

Hasan, S. (2009). Menakar Illegal Logging: Fiqih Lingkungan Hidup. Jurnal Hukum Islam, 1(1), 60-78.

Haryatmoko (2016). Membongkar Rezim Kepastian. Kanisius.

Koentjaraningrat (2010). Manusia dan Kebudayaan di Indonesia. Djambatan.

Muhlis, A. \& Norkholis. (2016). Analisis Tindakan Sosial Max Weber dalam Tradisi Pembacaan Kitab Mukhtasar Al-Bukhari (Studi Living Hadis). Jurnal Living Hadis, 1(2), 242-258.

Narindrani, F. (2018). Upaya Masyarakat dalam Pencegahan dan Pemberantasan Pembalakan Liar di Indonesia. De Jure: Jurnal Penelitian Hukum, 18(2), 241-256.

Peraturan Menteri Kehutanan Republik Indonesia Nomor P.38/MenhutII/2009 tentang Standard dan Pedoman Penilaian Kinerja Pengelolaan Hutan Produksi Lestari dan Verifikasi Legalitas Kayu pada Pemegang Izin atau pada Hutan Hak.

Ritzer, G. \& Goodman, D. J. (2010). Teori Sosiologi Modern. Kencana Prenada Media Group.

Soekanto, S. (2012). Sosiologi Suatu Pengantar. PT. RajaGrafindo Persada.

Sugiyono (2018). Metode Kuantitatif, Kualitatif, dan R\&D. Alfebeta.

Suyanto, B. \& Sutinah (2005). Metode Penelitian Sosial. Kencana Preneda Media Group.

Takwin, B. (2006). Habitus: Perlengkapan dan Kerangka Panduan Gaya Hidup dalam Resistensi Gaya Hidup: Teori dan Realitas. Jalasutra.

Swartz, D. (1997). Culture and Power: The Sociology of Pierre Bourdieu. The University of Chicago Press.

Sztompka, P. (2014). Sosiologi Perubahan Sosial. Kencana Prenada Media Group.

Widayanti, K. (2008). Sosialisasi Keberagaman Pada Anak (Studi tentang Peran Orang Tua dalam Pengenalan Agama kepada Anak di Desa Denhkeng Kecamatan Wedi Kabupaten Kelatena). Skripsi. Program Studi Sosiologi Agama Fakultas Ushuluddin Universitas Islam Negeri Sunan Kalijaga Yogyakarta. 